\title{
Spatial and temporal variability of natural regeneration in a temperate old-growth forest
}

\author{
Janusz SzEWCZYK*, Jerzy SzWAGRZYK \\ Department of Forest Botany and Nature Conservation, University of Agriculture, Al. 29 Listopada 46, 31-425 Krakow, Poland
}

(Received 13 March 2009; accepted 4 September 2009)

Keywords:

mixed temperate forest /

natural regeneration /

old-growth stand /

Western Carpathians
Mots-clés :

forêt mixte tempérée /

régénération naturelle /

vieux peuplements /

Carpates occidentaux

\begin{abstract}
- The natural regeneration of shade-tolerant tree species is characterized by large spatial heterogeneity and temporal variability. The mechanisms producing those patterns are still poorly understood and the knowledge of long-term fluctuations in regeneration processes is very limited.

- We used data from long-term study plots in an old-growth stand dominated by European beech and silver fir to address three questions: (1) Is a tendency towards clumping in seedlings associated with a particular spatial scale? (2) Are the spatial patterns in seedlings constant over time? (3) Is the distribution of seedlings related to light intensity?

- Over the study period the seedling density varied from 2.5 to 6 ind. $/ \mathrm{m}^{2}$. Stronger fluctuations occurred at a fine scale. Seedlings were clumped at distances ranging from a few centimeters to a few meters. The distribution of places with high seedling densities was relatively constant over time, especially in beech. Positive but weak rank correlations were found between light intensity and densities of beech and fir seedlings.

- Despite large fluctuations in seedlings densities, caused by mast-seeding, a permanent seedling bank was maintained. Very pronounced clumping of tree seedlings found in this study was only partially explained by differences in light intensity.
\end{abstract}

\footnotetext{
Résumé - Variabilité spatiale et temporelle d'une régénération naturelle dans une vieille forêt tempérée.

- La régénération naturelle des essences tolérantes à l'ombre est caractérisée par une grande hétérogénéité spatiale et une variabilité temporelle. Les mécanismes de production de ces modèles sont encore mal compris et la connaissance des fluctuations à long terme des processus de régénération est très limitée.

- Nous avons utilisé des données provenant d'études à long terme de parcelles, dans une vieille forêt ancienne dominée par le hêtre et le sapin pectiné, pour répondre à trois questions : (1) Y a-t-il une tendance à des bouquets de semis associée à une échelle spatiale particulière ? (2) Les modèles spatiaux des semis sont-ils constants dans le temps ? (3) La distribution des semis est-elle liée à l'intensité de la lumière?

- Au cours de la période d'étude, la densité des semis a varié de 2.5 à 6 ind. $/ \mathrm{m}^{2}$. De fortes fluctuations se sont produites à une échelle fine. Les plants étaient distribués en bouquets à des distances allant de quelques centimètres à quelques mètres. La distribution des emplacements avec des densités de semis élevées a été relativement constante au fil du temps, surtout avec le hêtre. Des corrélations positives mais faibles, ont été trouvées entre l'intensité de la lumière et les densités de semis de hêtre et de sapin.

- En dépit de fortes fluctuations des densités de semis, causées par la chute des graines, un stock permanent de semis a été maintenu. Des bouquets très marqués de semis, retrouvés dans cette étude n'ont été que partiellement expliqués par des différences dans l'intensité lumineuse.
}

\section{INTRODUCTION}

The natural regeneration of shade-tolerant tree species is characterized by large spatial heterogeneity and temporal vari-

\footnotetext{
*Corresponding author: rljszewc@cyf-kr.edu.pl
}

ability. The spatial heterogeneity of natural regeneration is relatively well documented (Cornett et al., 2000; Modrý et al., 2004). The first mechanism producing an uneven distribution of seedlings in space is variable seed availability, which is especially pronounced in the case of species with large seeds 
that are dispersed mainly by animals (Alvarez-Aquino and Williams-Linera, 2002). Attempts to explain the spatial heterogeneity of natural regeneration with the light conditions on the forest floor have been only partly successful (LePage et al., 2000; Wada and Ribbens, 1997). Another important factor is the presence of specific substrates that are conducive for seed germination and establishment of seedlings (Caspersen and Saprunoff, 2005; Gratzer et al., 1999; Mori and Mizumachi, 2005). However, a substantial portion of the variation in seedling density cannot be explained either by the availability of light or the presence of favorable microsites (Modrý et al., 2004; Paluch, 2005).

There is also increasing evidence that natural regeneration processes change over time (Beckage et al., 2005; Duchesneau and Morin, 1999; Houle, 1998). Long-living tree species are able, by the "storage effect", to maintain their share in a forest stand even if they regenerate successfully only once over many years (Warner and Chesson, 1985). In some places, seedlings of shade-tolerant species form a long-term seedling bank (Collet and Le Moguedec, 2007; Duchesneau and Morin, 1999; Parent et al., 2003). In other places, the almost continuous presence of seedlings on the forest floor relies strongly on the recurrent seed rain and vigorous germination, while the long-term survivorship of seedlings is close to zero (Szwagrzyk et al., 2001). In the latter case, differences in seedling densities can be driven either by masting in tree species (Alvarez-Aquino and Williams-Linera, 2002; Parent et al., 2003) or by weather factors affecting the germination process (Mori and Mizumachi, 2005).

The large spatial and temporal variability of regeneration processes in natural forests makes any generalizations based upon the data collected in short-term studies very doubtful. In this paper, we use data from long-term studies of natural regeneration in an old-growth mixed stand dominated by shadetolerant tree species - European beech Fagus sylvatica L. and silver fir Abies alba Mill. - to address three issues as follows: (1) to analyze the pattern of seedling distribution, starting from a fine scale (mapped and tagged individual seedlings), through the medium scale (sectors $-2 \mathrm{~m}^{2}$ ) to a coarse scale (circular plots $-28 \mathrm{~m}^{2}$ ), and to determine if a tendency towards clumping is associated with a particular spatial scale; (2) to examine whether the pattern of high and low densities is similar for germinants and for older seedlings, and to determine whether it is constant over time; and (3) to identify whether patches with higher seedling densities are confined to locations that are better illuminated, or if they are distributed independent of relative light intensity.

\section{MATERIAL AND METHODS}

\subsection{Study site}

The Żarnówka permanent research area is situated in the strictly protected zone of the Babia Góra National Park (Western Carpathians, Southern Poland; $19^{\circ} 30^{\prime}$ E, 49 40' N). The elevation is between 940 and $1010 \mathrm{~m}$, and the exposition is mostly to the North. The climate is cool and humid; the mean annual temperature is about $4{ }^{\circ} \mathrm{C}$, the sum of annual precipitation ranges between
1300 and $1400 \mathrm{~mm}$. Snow cover usually lasts from mid-November to mid-April and can attain a depth slightly over $1 \mathrm{~m}$. Dystric and eutric cambisols developed from sandstone (Carpathian flysh) predominate in this area. Forest stands are composed of European beech (the portion rising from $53.7 \%$ in 1991 to $59.0 \%$ in 2004), silver fir (the portion declining from $23.6 \%$ to $17.6 \%$ ), and Norway spruce (the portion changing slightly from $22.7 \%$ to $23.4 \%$ ). The area of remnant old-growth stand has been protected since the year 1933; prior to that time, it was a hunting preserve. No regular logging had ever been conducted in this locality.

\subsection{Field sampling}

Forest stands in an area of 1 ha $(100 \times 100 \mathrm{~m})$ were measured and mapped in 1991 (Szewczyk and Szwagrzyk, 1996), and then remeasured in 2004.

For the demographic study of young individuals, a set of 16 circular plots measuring $6 \mathrm{~m}$ in diameter spaced at $20 \times 20 \mathrm{~m}$ distances (maintaining $20 \mathrm{~m}$ buffers from the plot borders) was established in 1994 inside the 1 ha plot. Seedlings (including germinants) were counted annually in the plots from 1994-1999, and again from 20042006. The counting was conducted twice a year, in mid-June, when the germination in the Żarnówka area is more or less complete, and in mid-September. Five plots randomly selected out of the 16 were divided into eight sectors designed for the permanent monitoring of individuals. The areas between the sectors were left without measurements in order to avoid trampling of the labeled seedlings. A detailed design of the research plot was given in earlier paper (Szwagrzyk et al., 2001). Each seedling that germinated in a sector was mapped, measured and labeled with a plastic tag with a number attached using a thin wire. We also estimated the ages of seedlings by counting the annual height increments. In total, in 1994 we established 40 sectors of a size of $1.9 \mathrm{~m}^{2}$ each and followed the labeled seedlings from 1994-1999 and 2004-2006.

We measured relative light intensities at the sector level using the diazo-paper method (Friend, 1961). Two sets of diazo-paper booklets were exposed to light at 145 points distributed throughout the study area in mid-July in 2005. The number of diazo-paper booklets was higher in the 5 plots with exact measurements of individuals and lower in the 11 plots where the seedlings were counted but not measured. The first set of booklets was exposed for one week and the second for two weeks. After collecting, the diazo-papers were developed in ammonia and assessed visually. In the middle of July 2005, we conducted direct measurements of relative light intensities using LICOR 2000 at all 16 plots, measuring light intensities at eight points around each plot center and recording the average value. At the plotlevel both methods gave similar results $(r=0.64, p<0.01)$.

Tree seeds were collected using a set of regularly distributed seed traps measuring $0.5 \mathrm{~m}^{2}$. In each year the seed traps were placed approximately in the middle of the 16 plots. Seeds were collected in years: 1995, 1996, 1998, 1999, 2000, 2001, 2003 and 2004. Immediately after collection, the seeds were separated by species, counted and weighted.

\subsection{Data analysis}

The dataset that we used in this study included information on the exact location, species identity, year of establishment and survivorship of 1755 seedlings in 40 sectors distributed among five plots. 
Table I. Variance/mean ratio of germinants and seedlings in 40 sectors of five analyzed sample plots.

\begin{tabular}{ccccccc}
\hline Year & \multicolumn{2}{c}{ Beech } & \multicolumn{2}{c}{ Fir } & \multicolumn{2}{c}{ Spruce } \\
\cline { 2 - 7 } & Germinants & Seedlings & Germinants & Seedlings & Germinants & Seedlings \\
\hline 1994 & 2.45 & 6.36 & 1.59 & 3.05 & 0.95 & 2.51 \\
1995 & 1.45 & 4.97 & 0.93 & 2.76 & 0.98 & 1.33 \\
1996 & 51.34 & 3.57 & 1.36 & 2.43 & 0.83 & 1.08 \\
1997 & - & 24.66 & 0.93 & 1.64 & 2.83 & 1.29 \\
1998 & - & 22.27 & - & 1.61 & - & 1.56 \\
1999 & - & 21.41 & 1.99 & 1.58 & - & 1.65 \\
2004 & 0.98 & 11.36 & 2.63 & 3.13 & 2.54 & 1.68 \\
2005 & - & 10.64 & 0.95 & 3.83 & - & 1.85 \\
2006 & 1.55 & 10.07 & 4.10 & 2.49 & - & 1.18 \\
\hline
\end{tabular}

We also followed the fate of 293 tagged seedlings that were already present in the 40 sectors when we started our study in 1994. The data from the 11 remaining plots was used to determine if the seedling densities at the fine scale (40 sectors from five plots) differed from the larger scale ( 16 plots of the size of $28 \mathrm{~m}^{2}$ each). We employed the Kolmogorov-Smirnov test (Sokal and Rohlf, 1981) to compare the distributions of densities of germinants and seedlings at both scales.

As a measure of the clumping of individuals we used the standard variation/mean ratio (Pielou, 1974) calculated for 40 sectors from 1994-1999. To check the consistency of the empirical distribution of densities of germinants and seedlings, as well as the distributions of the relative light intensities with the normal distribution, we employed the Shapiro-Wilk W test. All computations were conducted using the STATISTICA 7.1 software. Because the distributions did not fit the normal curve we employed the Kendall's rank correlation coefficient $(\tau)$ to analyze the relationships between the densities of germinants and seedlings of various species and the relative light intensity. In a similar way we determined the relationship between the survival rates of seedlings and relative light intensity. To analyze if the spatial patterns of the germinants and seedlings densities were stable throughout time we employed the test of concordance (Kendall's $W$ - Sokal and Rohlf, 1981).

We also investigated the fine-scale spatial patterns of seedlings using the modified Ripley' L function (Wiegand and Moloney, 2004). These analyses were conducted in sectors where the seedlings were numerous enough (we chose seven seedlings per sector as a threshold value). In total, we calculated Ripley's L for the beech seedlings in the six sectors and for the fir seedlings in only one sector using the PROGRAMITA software developed by Wiegand (2008).

\section{RESULTS}

\subsection{Spatial variability}

The average annual density of germinants calculated for the 16 plots was equal to 2.84 ind. $/ \mathrm{m}^{2}$ for beech, $0.23 \mathrm{ind} . / \mathrm{m}^{2}$ for fir, and 0.03 ind. $/ \mathrm{m}^{2}$ for spruce. The distribution of the germinants was generally uneven, and it varied strongly among the years (Tab. I). Beech germinants were present in all sample plots at the beginning of our study and after the mast year in 1996. Silver fir was present in all plots only in 2006 (Tab. II). Viewed at a finer scale, beech germinants appeared at least once in all 40 sectors; silver fir germinants never appeared in 8 of the sectors $(20 \%)$ throughout entire study, and spruce germinants were absent in 27 sectors.
The variance/mean ratio calculated for the germinants attained an extremely high value (over 51) for beech in 1996. The variance/mean ratio had values below 1.0 only in the years with very low densities of germinants; the only exceptions were silver fir germinants in 1995 , when the density was moderate $\left(0.43 \mathrm{ind} . / \mathrm{m}^{2}\right)$ and the variance/mean ratio was only 0.93 (Tab. I).

A comparison of the distributions of germinant densities obtained at a fine scale (sector level) and at a larger scale (plot level) showed significant differences in the case of beech $(D=0.412, p<0.05)$ and spruce $(D=0.487, p<0.01)$. No significant differences were found for the germinants of silver fir or for seedlings of all three species.

Beech seedlings were present in all plots during from 1994-2001 until the year 2006 when two plots lost all of their beech seedlings. However, even in the year of highest seedling densities, beech was absent in some sectors; two sectors had no seedlings during our study. Silver fir seedlings were found in all sample plots throughout the study, but they appeared only in $72.5 \%$ of the sectors in the year 2006 . Spruce seedlings were present during the entire study in two plots out of the 16 total (Tab. II).

The spatial distribution of seedlings was aggregated (Tab. I), with the variance/mean ratios ranging from 1.08 (Norway spruce in 1996) to 24.66 (beech in 1997). The tendency for clumping was weakest in spruce and strongest in beech. However, even the very high values calculated for older seedlings never reached the levels ascertained for germinants. The variance/mean ratios reached their peak value in the 1996 beech cohort. With time, along with the decline in seedling density, the variance/mean ratio declined to slightly more than 10 in the year 2006 .

Seedlings of various species tended to occur in the same locations. We found significant positive rank correlations among densities of all three species. For beech and silver fir, a positive correlation was found in most cases (Kendall's $\tau$ from 0.22 in 1999 to 0.51 in 2006, $p<$ 0.05); the only exception was the period from 1997-1998, when the rank correlation between beech and fir densities was not significant $(\tau=0.18-0.19, p>0.05)$. Correlations between densities of fir and spruce were significant at the beginning of our study ( $\tau$ from 0.28 in 1994 to 0.29 in $1995, p<0.05$ ) and at its end ( $\tau$ from 0.30 in 2005 to 0.39 in $1999, p<0.05)$; at other times $(1996-1997)$ they were lower and insignificant $(\tau=0.19-0.20, p>0.05)$. Beech and spruce were quite strongly correlated in the years 1998-1999 and 2004-2006 ( $\tau$ from 0.25 in 1999 to 0.32 in $2006, p<0.05$ ).

The fine-scale spatial pattern of beech seedlings, analyzed using the Ripley's L method showed a tendency for clumping in all but one case (Fig. 1). The lines exceeding upper confidence limits indicated significant aggregation of seedlings. Statistically significant departures from a random distribution towards aggregation were 


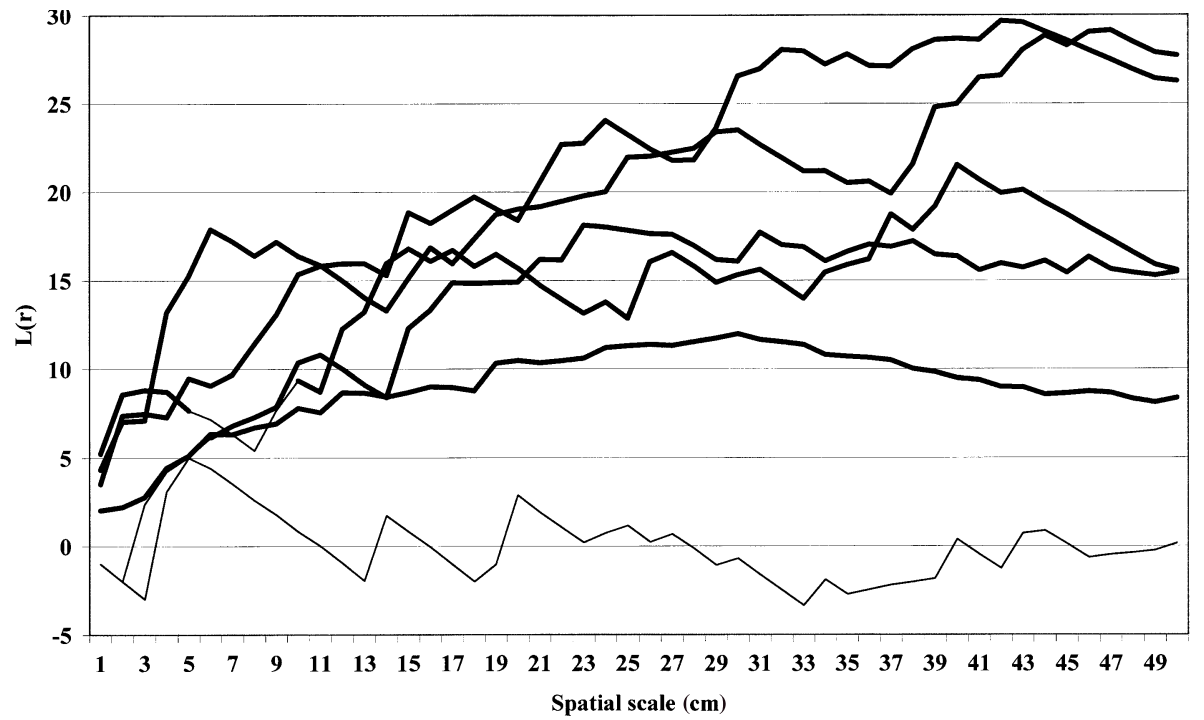

Figure 1. Fine-scale spatial patterns of beech seedlings analyzed using Ripley's L function in six sectors. Each line represents the results from one sector: thick line $-L(r)$ function exceeding the upper confidence limit; thin line $-L(r)$ function within the confidence envelope.

Table II. The share of plots/sectors occupied by germinants/seedlings in the years 1994-1999 and 2004-2006.

\begin{tabular}{|c|c|c|c|c|c|c|c|c|c|}
\hline \multirow[t]{2}{*}{ Species } & \multicolumn{9}{|c|}{ The share of plots/sectors (\%) } \\
\hline & 1994 & 1995 & 1996 & 1997 & 1998 & 1999 & 2004 & 2005 & 2006 \\
\hline & \multicolumn{9}{|c|}{ Germinants on 16 plots } \\
\hline Beech & 100.0 & 87.5 & 100.0 & 0.0 & 6.3 & 18.8 & 12.5 & 0.0 & 50.0 \\
\hline Fir & 6.3 & 87.5 & 93.8 & 12.5 & 6.3 & 87.5 & 50.0 & 37.5 & 100.0 \\
\hline \multirow[t]{2}{*}{ Spruce } & 12.5 & 6.3 & 75.0 & 18.8 & 0.0 & 12.5 & 18.8 & 12.5 & 0.0 \\
\hline & \multicolumn{9}{|c|}{ Germinants on 40 sectors } \\
\hline Beech & 32.5 & 20.0 & 95.0 & 0.0 & 0.0 & 0.0 & 2.5 & 0.0 & 17.5 \\
\hline Fir & 2.5 & 35.0 & 42.5 & 7.5 & 0.0 & 40.0 & 20.0 & 5.0 & 60.0 \\
\hline \multirow[t]{2}{*}{ Spruce } & 5.0 & 2.5 & 17.5 & 7.5 & 0.0 & 0.0 & 7.5 & 0.0 & 0.0 \\
\hline & \multicolumn{9}{|c|}{ Seedlings on 16 plots } \\
\hline Beech & 100.0 & 100.0 & 100.0 & 100.0 & 100.0 & 100.0 & 93.8 & 93.8 & 87.5 \\
\hline Fir & 100.0 & 100.0 & 100.0 & 100.0 & 93.8 & 93.8 & 93.8 & 93.8 & 100.0 \\
\hline \multirow[t]{2}{*}{ Spruce } & 87.5 & 81.3 & 75.0 & 62.5 & 62.5 & 56.3 & 43.8 & 31.3 & 25.0 \\
\hline & \multicolumn{9}{|c|}{ Seedlings on 40 sectors } \\
\hline Beech & 75.0 & 80.0 & 80.0 & 90.0 & 90.0 & 87.5 & 77.5 & 72.5 & 62.5 \\
\hline Fir & 72.5 & 72.5 & 72.5 & 60.0 & 60.0 & 60.0 & 60.0 & 60.0 & 65.0 \\
\hline Spruce & 300 & 30.0 & 27.5 & 22.5 & 22.5 & 20.0 & 12.5 & 10.0 & 12.5 \\
\hline
\end{tabular}

ascertained at spatial scales ranging from a few centimeters to $50 \mathrm{~cm}$ (Fig. 1). One distribution of beech seedlings was classified as random (at the distance of 4-6 cm the empirical line reached the upper limit of the confidence envelope, but it did not cross it). In case of silver fir, only one sector had enough seedlings to permit an analysis of pattern; the pattern was aggregated at the distance of $4-15 \mathrm{~cm}$.

\subsection{Changes in time}

The intensity of seed rain changed over time from almost no seeds in some years (as in 1996) to a few hundreds of seeds per square meter as in 1995 and 2003. Beech, with the average seed rain density of 118 seeds $/ \mathrm{m}^{2}$, was the most prolific seed producer, spruce was the second, and silver fir was third. The number of germinants varied substantially from year to year, especially in beech (Fig. 2). This was partly related to the density of the seed rain in the previous year, however, the percent of germinating seeds has also been changing through time (Tab. III). Among tree species, beech was characterized by the highest mean percentage of germinating seeds $(2.8 \%)$, while fir had an average percentage of $1.4 \%$, and spruce only $0.1 \%$. The relatively high percentage of germinating seeds in beech was the result of good germination $(6.1 \%)$ following the mast year of 1995 . The average percentage of germinating seeds calculated excluding the germinants from 1996 was much lower and almost equal to the percentage of germination in spruce $(0.06 \%)$. For silver fir the germination rates were more constant over time. Excluding the germinants from 1996 reduced the average percentage of germinating fir seeds only slightly, from $1.4 \%$ to $1.1 \%$.

Densities of seedlings older than one year also fluctuated in time, but the range of those changes was much narrower than in case of germinants (Fig. 2). At the beginning of our study the average density 

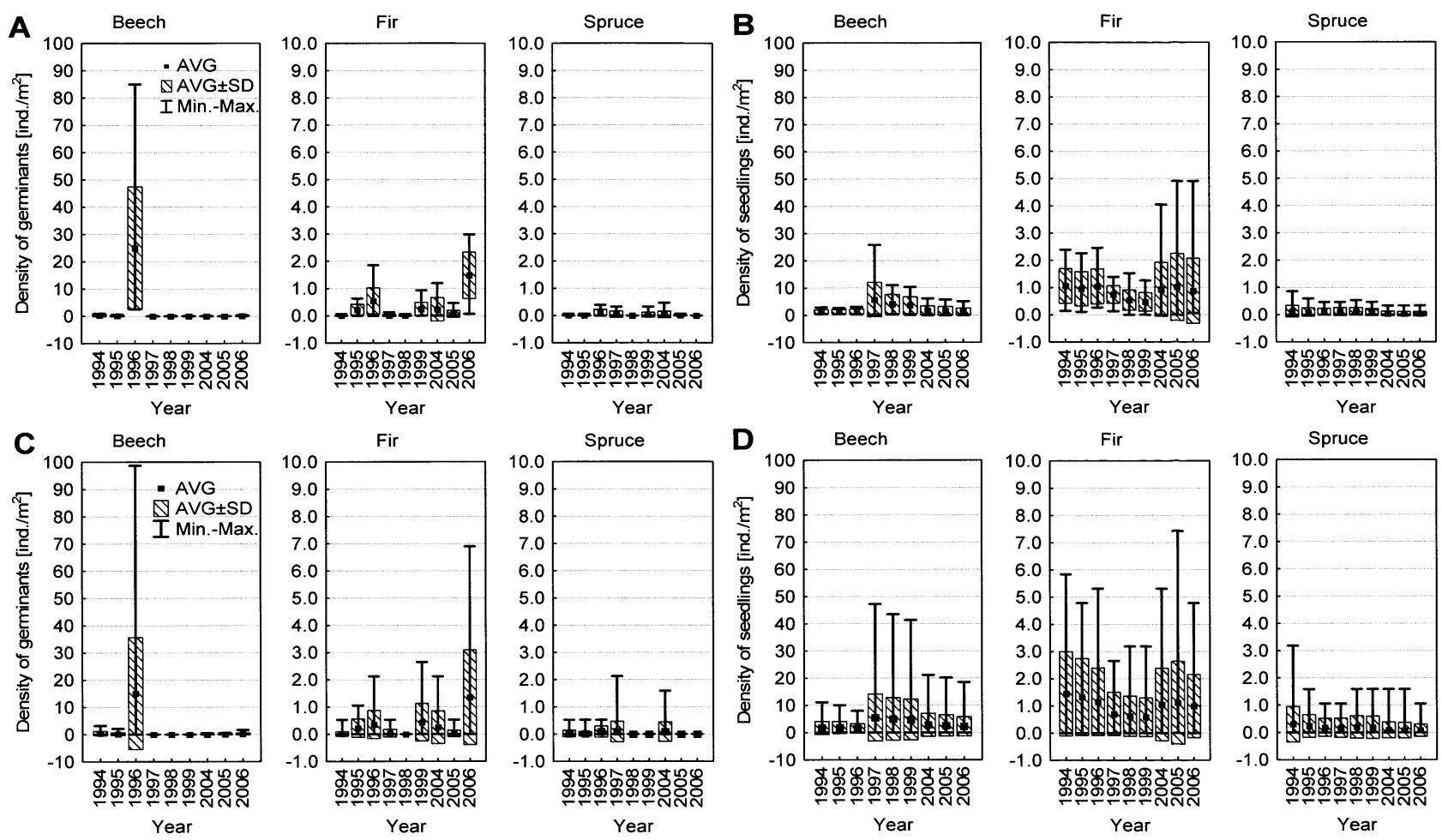

Figure 2. Densities of germinants and seedlings at two spatial scales: A - germinants on plots, B - seedlings on plots, C - germinants on sectors, D - seedlings on sectors. Explanations: black dot - average density, box - average density \pm standard deviation, whiskers - minimal and maximal density.

Table III. Temporal variability of seed germination, calculated on the basis of seeds collected in the given year and germinants found the following year.

\begin{tabular}{lrcr}
\hline Years & \multicolumn{3}{c}{$\begin{array}{c}\text { Percentage of germinating } \\
\text { seeds }(\%)\end{array}$} \\
\cline { 2 - 4 } & Beech & Fir & Spruce \\
\hline $1995 / 1996$ & 6.12 & 2.31 & 0.12 \\
$1996 / 1997$ & 0.00 & 3.33 & 1.67 \\
$1998 / 1999$ & 0.08 & 3.12 & $?^{*}$ \\
$1999 / 2000$ & 0.11 & 1.14 & 0.00 \\
$2003 / 2004$ & 0.01 & 0.64 & 0.03 \\
\hline Average & 2.83 & 1.39 & 0.11
\end{tabular}

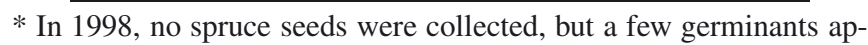
peared in two plots the following year.

of seedlings amounted to 2.5 individuals per square meter; half of that amount was beech and $41 \%$ was silver fir. Until 1999 the density of silver fir declined to 0.47 ind. $/ \mathrm{m}^{2}$. The density of beech increased rapidly in 1997 (to $5.71 \mathrm{ind} . / \mathrm{m}^{2}$ ) due to the establishment of a very numerous beech cohort in 1996. After 1999 the density of silver fir increased to $0.87 \mathrm{ind} . / \mathrm{m}^{2}$ in 2006 . The density of beech declined to 1.23 ind. $/ \mathrm{m}^{2}$ after 1996 (Fig. 2), as a result of seedling mortality and an almost complete lack of germination.

The spatial distribution of the plots with high and low densities of seedlings was relatively constant throughout time. The results of the tests of concordance (Kendall's $W$ ) in the years 1994-2006 were highly significant for beech $(W=0.3793, p<0.00001)$, silver fir
$(W=0.2258, p<0.00001)$ and spruce $(W=0.1254, p<0.00001)$. The test of concordance for the densities of the 1996 beech cohort yielded an even higher value $(W=0.7588, p<0.000001)$. The rank correlations between seedling density in 2006 and sum of germinants in the years from 1994-2006 were significant for beech $(\tau=0.58$, $p<0.0001)$, silver fir $(\tau=0.50, p<0.0001)$ and for spruce $(\tau=$ $0.56, p<0.0001)$.

\subsection{Relationship between natural regeneration and light intensity}

Light intensities at the sector level ranged from $0.37 \%$ to $21.85 \%$ for 128 sectors and from $0.92 \%$ to $10.41 \%$ for 40 sectors with detailed measurements. At the plot level relative light intensity varied from $0.64 \%$ to $12.14 \%$, measured with diazo-papers, and from $1.68 \%$ to $9.38 \%$ measured with LICOR 2000 - Table IV. Analyses conducted at the sector level yielded a significant positive relationship $(\tau=0.32$, $p<0.005$ ) between the relative light intensity in 2005 and the sum of beech germinants in the years from 1994-2006. Analyses conducted for germinants of spruce and fir showed no significant relationships ( $\tau=0.16, p>0.1$ for fir and $\tau=-0.05, p>0.5$ for spruce).

The analyses of the relationships between relative light intensity and seedling densities in 2006 resulted in positive Kendall's rank correlation for beech seedlings $(\tau=0.24, p<0.03)$ and silver fir seedlings $(\tau=0.27, p<0.02)$. The rank correlation for spruce was marginally insignificant $(\tau=0.20, p<0.1)$.

We also ascertained a positive significant relationship between the 10-year survivorship of the 1996 beech cohort and the relative light 
Table IV. Relative light intensities in 16 plots.

\begin{tabular}{lcccc}
\hline Plot number & $\begin{array}{c}\text { LICOR light } \\
\text { level }\end{array}$ & $\begin{array}{c}\text { Average from } \\
\text { 8 sectors }\end{array}$ & $\begin{array}{c}\text { Standard } \\
\text { deviation }\end{array}$ & $\begin{array}{c}\text { Coefficient } \\
\text { of variation } \\
\end{array}$ \\
\cline { 2 - 4 } & \multicolumn{3}{c}{ (\% of full sunlight) } \\
\hline 1 & 5.17 & 4.82 & 3.42 & 71.0 \\
2 & 1.73 & 0.64 & 0.25 & 38.9 \\
3 & 3.34 & 5.59 & 2.50 & 44.7 \\
4 & 5.61 & 12.14 & 5.99 & 49.3 \\
5 & 3.42 & 5.87 & 0.58 & 9.8 \\
6 & 1.68 & 0.76 & 0.13 & 16.8 \\
7 & 2.36 & 3.68 & 2.46 & 66.8 \\
8 & 2.84 & 2.92 & 2.44 & 83.5 \\
9 & 5.58 & 8.00 & 0.97 & 12.1 \\
10 & 3.69 & 2.95 & 2.62 & 88.8 \\
11 & 2.85 & 2.54 & 0.60 & 23.6 \\
12 & 4.48 & 9.07 & 6.34 & 69.9 \\
13 & 9.38 & 6.46 & 0.98 & 15.2 \\
14 & 3.47 & 5.93 & 4.60 & 77.7 \\
15 & 3.78 & 4.68 & 3.24 & 69.1 \\
16 & 2.23 & 2.25 & 1.76 & 78.1 \\
\hline
\end{tabular}

intensity $(\tau=0.26, p<0.05)$. Other analyses, employing the ratio of seedlings in 2006 to sum of germinants from 1994-2006 as a measure of long-term survivorship, and the relative light intensity, gave statistically insignificant results $(\tau=0.04, p>0.5$ for beech and $\tau=0.07$, $p>0.5$ for fir). In case of spruce the numbers of germinants were too small to determine the relationship.

The two sample plots with the lowest light intensities ascertained in 2005 were located in dense thickets of beech saplings. In 1994 the beech seedling densities amounted to 0.74 ind. $/ \mathrm{m}^{2}$ (in both plots), the fir seedling densities were 0.42 ind. $/ \mathrm{m}^{2}$ and $0.64 \mathrm{ind} . / \mathrm{m}^{2}$. By 2006 the seedling densities dropped to 0.07 ind. $/ \mathrm{m}^{2}$, and the only live seedlings in those plots were silver firs. The sums of saplings diameters per unit area had increased in that time by $167 \%$ in one plot and by $56 \%$ in another (Szwagrzyk and Szewczyk, 2008).

\section{DISCUSSION}

The results of our study confirmed the large spatial and temporal variability of demographic processes, reported in several recent publications (Abe et al., 2005; Alvarez-Aquino and Williams-Linera, 2002; Diaci et al., 2008; Paluch, 2005). Our results show, however, that there was a pattern of high and low seedling densities, which was relatively stable for more than ten years. The heterogeneity of light conditions at small to medium spatial scales was usually considered an important factor shaping the spatial variability of regeneration processes (Diaci et al., 2008). In our study we found positive and significant, but relatively weak, relationships between the relative light intensities and the densities of seedlings. Those relationships were slightly higher for silver fir than for beech. It is essential to note that the variability of light conditions explained only a small portion of the spatial variation in seedling densities. In our study, the relative intensity of light penetrating through the canopy of old-growth forest was higher and more variable than under canopies of managed mature beech stands
(Szwagrzyk et al., 2001), and in general it was conducive for the establishment of a long-term seedling bank. Similar findings have been reported in many studies conducted in temperate and boreal forests (Duchesneau and Morin, 1999; Modrý et al., 2004). However, under dense thickets of beech saplings the relative light intensities towards the end of the study period were probably too low to permit the long-term survival of seedlings. A similar relationship was described from southeastern Slovenia (Nagel et al., 2006), where dense sapling thickets were preventing the development of younger beech seedlings as well as from the Appalachian Mountains, where the presence of a dense shrub layer under forest canopy created conditions in which no seedlings were able to survive (Hille Ris Lambers and Clark, 2003). Similar mechanisms were also described in Asia, where presence of dense dwarf bamboo cover strongly affected the survivorship of tree seedlings (Abe et al., 2005; Gratzer et al., 1999; Nakashizuka, 2001). A similar trend was seen in South America (Gonzalez et al., 2002; Holz and Veblen, 2006).

The other important issue in our study is the temporal variability of seedling densities and survival rates. In young beech and fir the densities fluctuated with time, and the range of those fluctuations was related to the spatial scale: the largest fluctuations occurred at very local scale and the smallest at the entire plot level. However, even in the latter case the densities varied by more than $100 \%$ within $12 \mathrm{y}$ of study. The general picture was similar to that described by Houle (1998) from mixed oldgrowth stands in the eastern part of Canada, and by Osumi and Shobu (2002) from mixed deciduous second-growth stands in northern Japan. The processes of natural regeneration are strongly variable in time, making any generalizations drawn from short-term studies very risky (Houle, 1998; Parent et al., 2003).

One of the causes of fluctuations in seedling banks was mast-seeding; similar effects were found in Fagus grandifolia 
var. mexicana in Mexico, where seedling density increased fivefold after a mast year, and then declined abruptly (Alvarez-Aquino and Williams-Linera, 2002). However, contrary to the dense mature managed beech stands (Szwagrzyk et al., 2001), the decline in seedling density in our study was less intense and allowed for the formation of a long-term seedling bank with a fair proportion of older seedlings.

It is noteworthy to mention that some seedlings present in the seedling bank at the beginning of our study, or established after 1994, exceeded the threshold height of $0.5 \mathrm{~m}$ by the year 2006. Compared with the average density of beech saplings in the study area, which was equal to $0.65 \mathrm{ind} . / \mathrm{m}^{2}$ (Szwagrzyk and Szewczyk, 2008), the recruitment rate of saplings during our study $\left(0.015\right.$ ind. $/ \mathrm{m}^{2} /$ year) was relatively low. As beech is believed to be able to survive in the seedling stage for $30 \mathrm{y}$ (Korpel', 1995), this figure suggests that prior to the beginning of our study the recruitment rates of beech saplings were probably higher. We found no sapling recruitment in the other tree species present in the seedling bank - silver fir, Norway spruce and rowan, which were present among saplings in the study area at extremely low densities (Szwagrzyk and Szewczyk, 2008). In the case of silver fir and rowan, browsing by ungulates (which was irregular in time and space, but sometimes intense) could be responsible for their very slow growth.

A very interesting phenomenon recorded in this study was the uneven distribution of germinants and seedlings at the spatial scales ranging from a few centimeters to a few square meters. A high degree of clumping of tree seedlings has been frequently reported in the literature (Gratzer at al., 1999; Laliberte et al., 2008; Paluch, 2005), but in our study it was more extreme than in other cases. That clumping was not related to light intensity, as the relative light intensity did not show such steep gradients. The same refers to the seed rain intensity - it is spatially variable, but the differences at short distances are not large. The clumping of germinants and seedlings is also not related to the distribution of various substrates on the forest floor; the only microenvironment that is specific and widespread in the study area is coarse woody debris, covering about $6 \%$ of the ground surface. Other microsites, such as boulders and rocks, pits and mounds, moss mates and thick litter, covered in total only 5\% of the study area (Szewczyk and Szwagrzyk, 1996). All of the aggregations of germinants and seedlings found in our study were on ground covered with thin litter and not on logs or stumps. Coarse woody debris could be an important substrate for the regeneration of conifers (Szewczyk and Szwagrzyk, 1996), but it did not produce large differences in overall seedling densities.

One of plausible explanations for the large differences in seedling density among adjacent patches could be the activity of species-specific pathogenic fungi. Soil pathogens can accumulate, leading to a negative feedback between species abundance and recruitment rates (Packer and Clay, 2004). In the study area, several species of fungal pathogens from the genera Cylindrocarpon, Alternaria and Fusarium were identified during a pilot study conducted in the research area in 2001 and 2002. To test this hypothesis, a detailed study involving a quantitative and spatially explicit analysis of the distribution of soil fungi would be needed.
Concluding: despite large fluctuations in seedlings densities, caused by mast-seeding, a permanent seedling bank is maintained. Very pronounced clumping of tree seedlings found in this study is only partially explained by differences in light intensity.

Acknowledgements: We express our thanks to: M. Bartnik, P. Chrzan, A. Gazda, N. Jaroch, M. Łysik, M. Mączka, M. Ordyk, M. Piotrowski, S. Sarad, M. Sadecki, and T. Skrzydłowski, who contributed significantly to the field data collection and analysis. We would also like to thank Prof. E. Pancer-Koteja for valuable comments on the earlier version of this manuscript. This study was supported by the research grants: 6 P205 00907 and 3 P04F 07024 by the Polish Ministry of Science and Higher Education.

\section{REFERENCES}

Abe M., Miguchi H., Honda A., Makita A., and Nakashizuka T., 2005. Short-term changes affecting regeneration of Fagus crenata after the simultaneous death of Sasa kurilensis. J. Veg. Sci. 16: 49-56.

Alvarez-Aquino C. and Williams-Linera G., 2002. Seedling bank dynamics of Fagus grandifolia var. mexicana before and after a mast year in a Mexican cloud forest. J. Veg. Sci. 13: 179-184.

Beckage B., Lavine M., and Clark J.S., 2005. Survival of tree seedlings across space and time: estimates from long-term count data. J. Ecol. 93: $1177-1184$.

Caspersen J.P. and Saprunoff M., 2005. Seedling recruitment in a northern temperate forest: the relative importance of supply and establishment limitation. Can. J. For. Res. 35: 978-989.

Collet C. and Le Moguedec G., 2007. Individual seedling mortality as a function of size, growth and competition in naturally regenerated beech seedlings. Forestry 80: 359-370.

Cornett M.W., Reich P.B., Puetmann K.J., and Frelich L.E., 2000. Seedbed and moisture availability determine safe sites for early Thuja occidentalis (Cupressaceae) regeneration. Am. J. Bot. 87: 1807-1814.

Diaci J., Gyoerek N., Gilha J., and Nagel T.A. 2008. Response of Quercus robur L. seedlings to north-south asymmetry of light within gaps in floodplain forests of Slovenia. Ann. For. Sci. 65: 105, 8 p.

Duchesneau R. and Morin H., 1999. Early seedling demography in balsam fir seedling banks. Can. J. For. Res. 29: 1502-1509.

Friend D.T.C., 1961. A simple method for measuring integrated light values in the field. Ecology 42: 577-580.

Gonzalez M.E., Veblen T.T., Donoso C., and Valeria L., 2002. Tree regeneration responses in a lowland Nothofagus-dominated forest after bamboo dieback in South-Central Chile. Plant Ecol. 161: 59-73.

Gratzer G., Rai P.B., and Glatzel G., 1999. The influence of the bamboo Yushania microphylla on regeneration of Abies densa in central Bhutan. Can. J. For. Res. 29: 1518-1527.

Hille Ris Lambers J. and Clark J.S., 2003. Effects of dispersal, shrubs and density-dependent mortality on seed and seedling distributions in temperate forests. Can. J. For. Res. 33: 783-795.

Holz C.A. and Veblen T.T., 2006. Tree regeneration responses to Chusquea montana bamboo die-off in a subalpine Nothofagus forest in the southern Andes. J. Veg. Sci. 17: 19-28.

Houle G., 1998. Seed dispersal and seedling recruitment of Betula alleghaniensis: spatial inconsistency in time. Ecology 79: 807-818.

Korpel' Š., 1995. Die Urwälder der Westkarpaten. Gustav Fischer Verlag, Stuttgart, $310 \mathrm{p}$.

Laliberté E., Cogliastro A., and Bouchard A., 2008. Spatiotemporal patterns in seedling emergence and early growth of two oak species direct-seeded on abandoned pastureland. Ann. For. Sci. 65: 407. 
LePage P.T., Canham C.D., Coates D., and Bartemucci P., 2000. Seed abundance versus substrate limitation of seedling recruitment in northern temperate forests of British Columbia. Can. J. For. Res. 30: 415-427.

Modrý M., Hubený D., and Rejšek K., 2004. Differential response of naturally regenerated European shade tolerant tree species to soil type and light availability. For. Ecol. Manage. 188: 185-195.

Mori A. and Mizumachi E., 2005. Season and substrate effects on the first-year establishment of current-year seedlings of major conifer species in an old-growth subalpine forest in Japan. For. Ecol. Manage. 210: 461-467.

Nagel T.A., Svoboda M., and Diaci J., 2006. Regeneration patterns after intermediate wind disturbance in an old-growth Fagus-Abies forest in southeastern Slovenia. For. Ecol. Manage. 226: 268-278.

Nakashizuka T., 2001. Species coexistence in temperate mixed deciduous forests. Trends Ecol. Evol. 16: 205-210.

Osumi K. and Shobu S., 2002. The unstable fate of seedlings of the smallseeded pioneer tree species, Betula maximowicziana. For. Ecol. Manage. 160: 85-95.

Packer A. and Clay K., 2004. Development of negative feedback during successive growth cycles of black cherry. Proc. R. Soc. B: Biol. Sci. $271,317-324$.

Paluch J., 2005. Spatial distribution of regeneration in West-Carpathian uneven-aged silver fir forests. Eur. J. For. Res. 124: 47-54.

Parent S., Simard M.J., Morin H., and Messier C., 2003. Establishment and dynamics of the balsam fir seedling bank in old forests of northeastern Quebec. Can. J. For. Res. 33: 597-603.
Pielou E.C., 1974. Population and community ecology. Gordon and Breach Science Publishers, New York, 424 p.

Sokal R.R. and Rohlf F.J., 1981. Biometry, 2nd ed., W.H. Freeman and Company, New York, 859 p.

Szewczyk J. and Szwagrzyk J., 1996. Tree regeneration on rotten wood and on soil in old-growth stand. Plant Ecol. 122: 37-46.

Szwagrzyk J. and Szewczyk J., 2008. Is natural regeneration of forest stands a continuous process? A case study of an old-growth forest of the Western Carpathians. Pol. J. Ecol. 56: 623-633.

Szwagrzyk J., Szewczyk J., and Bodziarczyk J., 2001. Dynamics of seedling banks in beech forest: result of 10-year study on germination, growth and survival. For. Ecol. Manage. 141: 237-250.

Wada N. and Ribbens E., 1997. Japanese maple (Acer palmatum var. Matsumurae, Aceraceae) recruitment patterns: seeds, seedlings and saplings in relation to conspecific adult neighbors. Am. J. Bot. 84: 1294-1300.

Warner R.R. and Chesson P.L. 1985. Coexistence mediated by recruitment fluctuations: a field guide to the storage effect. Am. Nat. 125: 769-787.

Wiegand T., 2008. Programita, a software to perform point pattern analysis with Ripley's L and O-ring statistic. Available from: http://www. thorsten-wiegand.de/towi_download_manual.html.

Wiegand T. and Moloney K.A., 2004. Rings, circles, and null-models for point pattern analysis in ecology. Oikos 104: 209-229. 